\title{
Fatty acid profiles in marine and freshwater fish from fish markets in northeastern Poland
}

\author{
Joanna Łuczyńska, Beata Paszczyk, Marek J. Łuczyński
}

Received - 07 January 2014/Accepted - 14 April 2014. Published online: 30 September 2014; $\odot$ Inland Fisheries Institute in Olsztyn, Poland Citation: Łuczyńska J., Paszczyk B., Łuczyński M.J. 2014 - Fatty acid profiles in marine and freshwater fish from fish markets in northeastern Poland - Arch. Pol. Fish. 22: 181-188.

\begin{abstract}
The fatty acid compositions were studied in eight commercially important fish from fish markets: salmon, Salmo salar L.; cod, Gadus morhua L.; common sole, Solea solea (L.); European flounder, Platichthys flesus (L.); catfish, Clarias gariepinus (Burchell); rainbow trout, Oncorhynchus mykiss (Walb.); Nile tilapia, Oreochromis niloticus (L.); and pangasius, Pangasianodon hypophthalmus (Sauvage). The freshwater fish contained 25.69-42.18\% saturated, 34.90-43.79\% monounsaturated, 8.46-16.32\% n-6 polyunsaturated, and 5.01-20.43\% n-3 polyunsaturated acid, while marine fish contained $18.53-32.77 \%$ saturated, 17.95-49.89\% monounsaturated, 3.40-11.51\% n-6 polyunsaturated, and $18.74-45.42 \% \mathrm{n}-3$ polyunsaturated acid. Marine fish contained significantly more $\Sigma$ n-3 PUFA (29.79\%), EPA (12.26\%), DHA (13.20\%), and a higher n-3/n-6 (6.95) ratio than freshwater fish (13.13, 2.47, 7.14, $1.29 \%)(\mathrm{P} \leq 0.05)$. There were statistically significant differences in the $n-3 / n-6$ ratio among fish species (cod $(13.40)>$ sole $(8.47)>$ flounder $(4.30)>$ rainbow trout $(2.41)$ $>$ catfish $(1.83) \approx \operatorname{salmon}(1.63)>$ tilapia $(0.57) \approx$ pangasius (0.36) $(\mathrm{P} \leq 0.05))$.
\end{abstract}

Keywords: freshwater, marine, eicosapentaenoic acid, docosahexaenoic acid

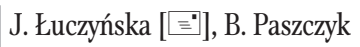

Chair of Commodity Science and Food Analysis

University of Warmia and Mazury in Olsztyn, Poland

Plac Cieszyński 1, 10-957 Olsztyn-Kortowo, Poland

Tel. (89) 5234165, e-mail: jlucz@uwm.edu.pl

M.J. Łuczyński

Department of Aquaculture, Inland Fisheries Institute in Olsztyn, Poland

\section{Introduction}

Fish lipids are rich sources of long chain n-3 polyunsaturated fatty acid, especially $\alpha$-linolenic acid (C18:3, ALA), eicosapentaenoic (C20:5, EPA) and docosahexaenoic (C22:6, DHA) (Holub and Holub 2004, Lecerf 2007, DeFilippis et al. 2010). According to Kris-Etherton et al. (2002), these acids influence arrhythmia, blood pressure, and hypotriglyceridemia. Attention is also paid to linoleic (C18:2n-6) and arachidonic (C20:4n-6) acids, the latter of which is synthesized from the former (Głogowski and Ciereszko 2001). Humans also have a limited ability to synthesize EPA and DHA, which means they must consume them with food or rely on enzymatic transmutations of $\alpha$-linolenic acid to make them in their systems (Lecerf 2007). The data in the literature indicate that both marine and freshwater fish are good sources of polyunsaturated fatty acids (Özogul et al. 2007, Visentainer et al. 2007, Łuczyńska et al. 2008, Diraman and Dibeklioglu 2009). Polak-Juszczak (2007) reports that several new fish species available on the Polish market, e.g., Ruvettus pretiosus Cocco, Lates niloticus (L.), Clarias gariepinus (Burchell), and Pangasianodon hypophthalmus (Sauvage), are characterized by low amounts of n-3 fatty acids in relation to Baltic fish. Drobná et al. (2006) found that n-3 PUFA in rainbow trout, Oncorhynchus mykiss (Walb.), depended on its 
diet, but the content of fatty acids also differed among species (Kołakowska et al. 2000, Haliloðlu et al. 2002, Grela and Dudek 2007, Bienkiewicz et al. 2008). Consequently, the objective of this study was to determine if different freshwater and marine fish species had different fatty acid profiles, and if freshwater fish are as good a source of these fatty acids as are marine fish.

\section{Material and methods}

All the samples of fresh fish fillets from salmon, Salmo salar L., cod, Gadus morhua L., and catfish $C$. gariepinus, and gutted flounder Platichthys flesus (L.) and rainbow trout, O. mykiss Walb., and frozen fillets of sole, Solea solea (L.), tilapia, Oreochromis niloticus (L.) and pangasius, $P$. hypophthalmus, were bought in the January-February 2009 period at markets in northeastern Poland. The fish and fillets were transported to the laboratory. Dorsal muscles (without skin) were excised from fresh, gutted fish, and skinned fresh fish fillets were mixed and then were frozen in polyethylene bags and kept at $-25^{\circ} \mathrm{C}$ until analysis on the following day. The frozen fillets were defrosted, mixed, and analyzed on the same day. Samples from salmon, sole, rainbow trout, catfish, tilapia, and pangasius, comprised individual specimens (Table 1). Flounder samples were prepared from muscle tissue taken from two fish, and cod samples were prepared from the muscles from one (weight of fillets $>240 \mathrm{~g}$ ) or three fish (weight of fillets $<146 \mathrm{~g}$ ).

Lipids were extracted from muscles (each sample in duplicate) according to the method described by Berg and Nilsson (1997). The fats necessary for fatty acids analysis were prepared using cold extraction methods by Folch as described by Christie (1973) using a chloroform-methanol mixture at a ratio of 2:1. The fatty acid methyl esters were prepared with the Peisker method in a mixture of chloroform: methanol: sulfuric acid (100:100:1 v/v; Żegarska et al. 1991). The fatty acid profiles were determined with the capillary gas chromatographic method. The fatty acids were analyzed on an Agilent Gas
Chromatograph $6890 \mathrm{~N}$ with a flame-ionization detector (FID). The instrument conditions were as follows: capillary column (dimensions - $30 \mathrm{~m}$ x 0.25 $\mu \mathrm{m}$ with a $0.32 \mathrm{~mm}$ internal diameter, liquid phase Supelcowax 10); the injector, flame ionization detector and column temperature were 225, 250, and $190^{\circ} \mathrm{C}$, respectively, and the helium carrier gas flow was $1 \mathrm{~cm}^{3} \mathrm{~min}^{-1}$. Individual fatty acids were identified by comparing the relative retention time peaks to known Supelco standards.

Statistically significant differences in the contents of fatty acids and n-3/n-6 ratio among species were calculated using one-way analysis of variance ANOVA (Duncan's test). Significant differences among the contents of fatty acids in muscle lipids of marine and freshwater fish were calculated using test $t$ for independent samples. Bartlett's test for homogeneity of variance was also performed to determine if variances in different groups were homogenous. In all cases, statistical significance was $\mathrm{P} \leq 0.05$. The contents of fatty acids in the muscles of fish are expressed in percentages of the total fatty acids.

\section{Results}

In the present study, the content of fatty acids varied within and among some species. Saturated fatty acids ranged between 18.53 and $42.18 \%$ (Table 2). The significantly highest percentage value of SFA ( $\mathrm{P} \leq$ 0.05) was noted in pangasius, whereas salmon (18.53\%) had the lowest content of saturated fatty acids $(\mathrm{P} \leq 0.05)$. The percentage range of MUFA was 17.95-49.89\%. Salmon contained significantly higher amounts of monounsaturated fatty acids $(\mathrm{P} \leq$ 0.05) than the other fish examined with the exception of flounder. The lowest content of MUFA was noted in $\operatorname{cod}(\mathrm{P} \leq 0.05)$. The percentages of SFA (35.20 and 26.42\%, respectively), C16:0 (24.30 and 17.40\%, respectively), and C18:1 (27.69 and $22.06 \%$, respectively) ( $\mathrm{P} \leq 0.05)$ were significantly different between freshwater and marine fish, but the differences of MUFA in the freshwater and marine fish (38.47 and $36.75 \%$, respectively) were not 


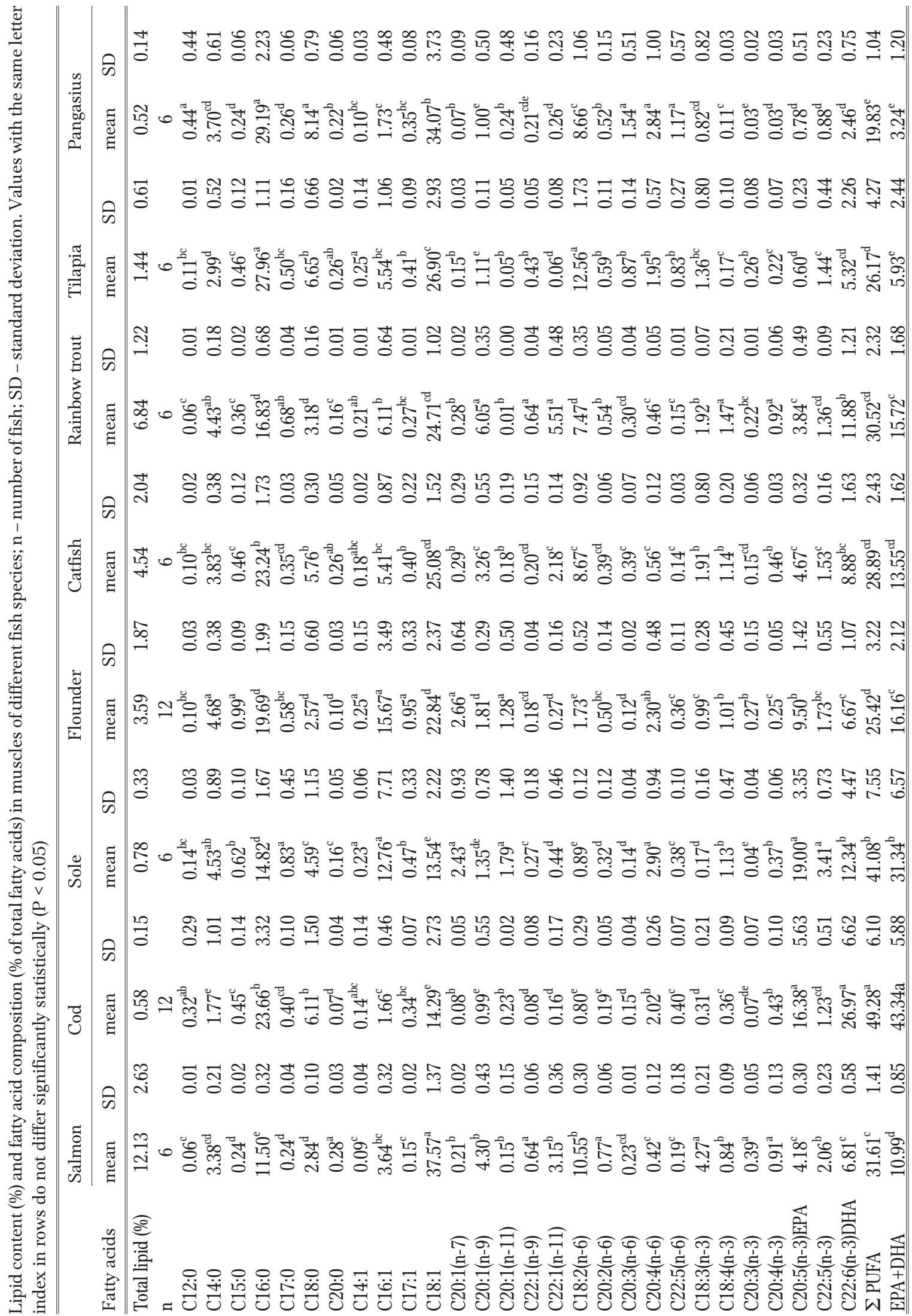


Table 2

Differences in the content of sum group fatty acids and n-3/n-6 ratios in muscle lipids of the fish examined (\% of total fatty acids; mean $\pm \mathrm{SD})$

\begin{tabular}{llllll}
\hline \hline Fatty acids & SFA & MUFA & n-6 PUFA & n-3 PUFA & $\mathrm{n}-3 / \mathrm{n}-6$ \\
\hline \hline Marine fish & & & & & \\
$\quad$ Salmon & $18.53^{\mathrm{e}} \pm 0.37$ & $49.89^{\mathrm{a}} \pm 1.16$ & $11.51^{\mathrm{a}} \pm 0.45$ & $18.74^{\mathrm{c}} \pm 1.24$ & $1.64^{\mathrm{de}} \pm 0.14$ \\
$\quad$ Cod & $32.77^{\mathrm{c}} \pm 5.71$ & $17.95^{\mathrm{d}} \pm 2.59$ & $3.40^{\mathrm{e}} \pm 0.33$ & $45.42^{\mathrm{a}} \pm 6.02$ & $13.40^{\mathrm{a}} \pm 1.59$ \\
$\quad$ Sole & $25.67^{\mathrm{d}} \pm 2.35$ & $33.27^{\mathrm{c}} \pm 9.70$ & $4.34^{\mathrm{d}} \pm 1.11$ & $35.52^{\mathrm{b}} \pm 7.20$ & $8.47^{\mathrm{b}} \pm 2.03$ \\
$\quad$ Flounder & $28.72^{\mathrm{d}} \pm 2.09$ & $45.90^{\mathrm{ab}} \pm 3.51$ & $4.58^{\mathrm{d}} \pm 0.69$ & $19.49^{\mathrm{c}} \pm 2.53$ & $4.30^{\mathrm{c}} \pm 0.55$ \\
Freshwater fish & & & & & \\
$\quad$ & & & & \\
African catfish & $33.99^{\mathrm{c}} \pm 1.96$ & $37.16^{\mathrm{c}} \pm 0.54$ & $9.82^{\mathrm{bc}} \pm 0.86$ & $17.83^{\mathrm{c}} \pm 2.10$ & $1.83^{\mathrm{de}} \pm 0.27$ \\
$\quad$ Rainbow trout & $25.69^{\mathrm{d}} \pm 0.65$ & $43.79^{\mathrm{b}} \pm 1.94$ & $8.46^{\mathrm{c}} \pm 0.58$ & $20.43^{\mathrm{c}} \pm 2.27$ & $2.41^{\mathrm{d}} \pm 0.17$ \\
$\quad$ Tilapia & $38.94^{\mathrm{b}} \pm 1.55$ & $34.90^{\mathrm{c}} \pm 3.58$ & $16.32^{\mathrm{a}} \pm 2.19$ & $9.24^{\mathrm{d}} \pm 3.53$ & $0.57^{\mathrm{e}} \pm 0.22$ \\
$\quad$ Pangasius & $42.18^{\mathrm{a}} \pm 3.08$ & $38.02^{\mathrm{c}} \pm 3.43$ & $14.29^{\mathrm{a}} \pm 1.69$ & $5.01^{\mathrm{d}} \pm 1.46$ & $0.36^{\mathrm{e}} \pm 0.15$ \\
\hline \hline
\end{tabular}

SFA - saturated fatty acids; MUFA - monounsaturated fatty acids; PUFA - polyunsaturated fatty acids; SD - standard deviation. Values with the same letter index in columns do not differ significantly statistically $(\mathrm{P}<0.05)$

Table 3

Differences in the content of sum group fatty acids and n-3/n-6 ratios in the muscle lipids of marine and freshwater fish (\% of total fatty acids) (mean $\pm \mathrm{SD})$

\begin{tabular}{lll}
\hline \hline Fatty acids & Marine fish & Freshwater fish \\
\hline \hline C16:0 & $17.4^{\mathrm{b}} \pm 5.13$ & $24.30^{\mathrm{a}} \pm 5.17$ \\
$\mathrm{C} 18: 1$ & $22.06^{\mathrm{b}} \pm 10.10$ & $27.69^{\mathrm{a}} \pm 4.53$ \\
$\mathrm{C} 18: 2 \mathrm{n}-6$ & $3.49^{\mathrm{b}} \pm 4.19$ & $9.34^{\mathrm{a}} \pm 2.23$ \\
C20:4 n-6 & $1.91^{\mathrm{a}} \pm 1.07$ & $1.45^{\mathrm{a}} \pm 1.15$ \\
$\Sigma$ SFA & $26.42^{\mathrm{b}} \pm 6.13$ & $35.20^{\mathrm{a}} \pm 6.62$ \\
$\Sigma$ MUFA & $36.75^{\mathrm{a}} \pm 13.68$ & $38.47^{\mathrm{a}} \pm 4.18$ \\
$\Sigma \mathrm{n}-6$ PUFA & $5.96^{\mathrm{b}} \pm 3.74$ & $12.22^{\mathrm{a}} \pm 3.70$ \\
$\Sigma$ n-3 PUFA & $29.79^{\mathrm{a}} \pm 12.98$ & $13.13^{\mathrm{b}} \pm 7.22$ \\
EPA & $12.26^{\mathrm{a}} \pm 6.72$ & $2.47^{\mathrm{b}} \pm 1.88$ \\
DHA & $13.20^{\mathrm{a}} \pm 9.25$ & $7.14^{\mathrm{b}} \pm 3.92$ \\
n-3/n-6 ratio & $6.95^{\mathrm{a}} \pm 5.14$ & $1.29^{\mathrm{b}} \pm 0.99$ \\
\hline
\end{tabular}

SFA - saturated fatty acids; MUFA - monounsaturated fatty acids; PUFA - polyunsaturated fatty acids; EPA - eicosapentaenoic acid; DHA - docosahexaenoic acid; SD - standard deviation. Values with the same letter index in rows do not differ significantly statistically $(\mathrm{P}<0.05)$

statistically significant $(\mathrm{P}>0.05$; Table 3$)$. Palmitic acid (C16:0) dominated the saturated fatty acid group. The most abundant monounsaturated fatty acid in all the fish studied was oleic acid (C18:1; Table 1). The content of palmitic acid in pangasius $(29.19 \%)$ and tilapia (27.96\%) was significantly higher than in the other fish examined $(\mathrm{P} \leq 0.05)$, whereas the lowest value of this acid $(11.50 \%)$ was noted in salmon $(\mathrm{P} \leq 0.05)$ (Table 1). The highest amount of oleic acid (C18:1) in salmon (37.57\%) was significantly different than that in the other fish studied $(\mathrm{P} \leq 0.05)$. In the present study, cod (14.29\%) and sole (13.54\%) had the lowest values of oleic acid $(\mathrm{P} \leq 0.05)$.

Pangasius (14.29\%) and tilapia (16.32\%) had the highest contents of $n-6$ PUFA ( $P \leq 0.05$ ), whereas the lowest amount of this fatty acid group (3.40\%) was observed in cod $(\mathrm{P} \leq 0.05)$ (Table 2$)$, but the opposite was noted for n-3 polyunsaturated fatty acids $(\mathrm{P} \leq 0.05)$. The $\mathrm{n}-3$ PUFA varied from 5.01 to 45.42\%. Freshwater fish had more n-6 PUFA (12.22\%) and C18:2 (9.34\%) than marine fish (5.96 
and 3.49\%, respectively) ( $\mathrm{P} \leq 0.05$; Table 3). The opposite was observed for n-3 PUFA, DHA, and EPA (P $\leq 0.05$ ), whereas the differences in C20:4 n-6 in marine and freshwater fish did not differ significantly $(\mathrm{P}$ $>0.05)$. The contents of $n-3$ PUFA, EPA, DHA, and C20:4 n-6 in freshwater fish were 13.13, 2.47, 7.14 and $1.45 \%$, respectively, whereas n-3 PUFA, EPA, DHA, and C20:4 n-6 accounted for 29.79, 12.26, 13.20 , and $1.91 \%$ in marine fish.

In all the fish examined, the most abundant n- 6 polyunsaturated fatty acids were linoleic $(\mathrm{C} 18: 2 \mathrm{n}-6)$ and arachidonic (C20:4 n-6; Table 1). The amounts of docosahexaenoic (C22:6 DHA) and eicosapentaenoic (C20:5 EPA) were predominant among n-3 PUFAs (Table 1). The percentage of linoleic acid ranged from 0.80 to $12.56 \%$ and was the highest in tilapia $(\mathrm{P} \leq 0.05)$ (Table 1). Cod had the lowest values of linoleic acid ( $\mathrm{P} \leq$ $0.05)$, but the percentage of this fatty acid was not significantly different $(\mathrm{P}>0.05)$ between cod and two marine fish species (sole and flounder). The level of C20:4 n-6 varied between 0.46 and 2.90\%. Arachidonic acid did not differ statistically significantly in the following groups: sole, pangasius, and flounder; flounder, cod, and tilapia; catfish, rainbow trout, and salmon $(\mathrm{P} \leq$ 0.05). The percentage of EPA was significant higher in sole $(19.00 \%)$ and cod (16.38\%), while cod had more DHA (26.97\%) than the other fish examined ( $\mathrm{P} \leq 0.05)$. Significantly lower values of EPA $(0.60 \%)$, with the exception of pangasius, were noted in tilapia ( $(\mathrm{P} \leq 0.05)$. Pangasius had significantly the lowest value of DHA $(2.46 \%)$ among all the fish except for tilapia ( $\mathrm{P} \leq 0.05)$.

The $n-3 / n-6$ ratio ranged from 0.36 (pangasius) to 13.40 (cod) (Table 2). The $n-3 / n-6$ ratio was not statistically significantly different in the following groups: cod; sole; flounder; rainbow trout; catfish and salmon; tilapia and pangasius; $\mathrm{P} \leq 0.05)$. Similarly, significant differences in the $n-3 / n-6$ ratios were noted in marine $(6.95 \%)$ and freshwater fish (1.29\%) (P $\leq$ 0.05; Table 3).

\section{Discussion}

The content of fatty acids groups varied among some of the species studied. Previous studies also noted significant differences among the fatty acids profiles (SFA, MUFA, PUFA) of other freshwater and marine fish species (Diraman and Dibeklioglu 2009). According to Ho and Paul (2009), pangasius contained more SFA (42.63\%) than Atlantic salmon (29.56\%) and barramundi, Lates calcarifer (Bloch) (34.15\%). These values are close to those for pangasius in the current study (Table 2), whereas they are higher to those for the salmon studied. Grela and Dudek (2007) did not report differences in SFA content between cod (33.12\%) and salmon (31.47\%). These findings are not in agreement with those of the present study. Haliloğlu et al. (2002) also observed higher amounts of SFA in the muscle lipid of rainbow trout (31.92\%). Similar observations for catfish were made by Kwetegyeka et al. (2008), who also report that the content of saturated fatty acids in tilapia from Lwampanga at Lake Kyonga is $38.7 \%$, which is comparable to that measured in the same fish species from the present study. The values of MUFA in the fish examined (Table 2) are higher to those found by the authors cited above. Ho and Paul (2009) observed lower values of MUFA in pangasius and salmon than those reported in the present study.

Suloma et al. (2008) and Osibona (2011), who both studied fatty acids in tilapia and catfish, also found that palmitic and oleic acid were dominant among the SFA and MUFA, respectively. These results are consistent to those for rainbow trout fillets reported by Kalyoncu et al. (2010). Similar regularities were also reported previously by Visentainer et al. (2007) for marine fish species. The values reported by Bienkiewicz and Domiszewski (2008) for the palmitic acid content in pangasius (29.21\%) was close, whereas that of oleic acid was higher (43.36\%) that those of the same fish species in the current study. The current results of C16:0 in pangasius are consistent with those of Ho and Paul (2009), who also found differences in the amounts of palmitic and oleic acid (C18:1 n-9) between pangasius and Atlantic salmon. Interspecific differences in the content of C18:1 acid in salmon and cod were observed by Grela and Dudek (2007). Salmon had more oleic acid $(33.17 \%)$ than cod $(20.26 \%)$. The results of palmitic and oleic acid in flounder were 22.70 and 
$22.24 \%$, respectively (Kołakowska et al. 2000). The values of oleic acid were close to those measured in the present study in contrast to those of palmitic acid.

Kwetegyeka et al. (2008) reported that instead of total n-6 PUFA, tilapia had more n-3 PUFA (31.2-32.0\%) than catfish (24.0-24.6\%). This differs from the data from the current study, with values that are higher to those from same fish species in the present study (Table 2). Similar contents of n-3 (11.5\%) and n-6 PUFA (11.6\%) in African catfish from Turkey were observed by Özogul et al. (2007). Bienkiewicz and Domiszewski (2008) detected higher values of n-6 polyunsaturated fatty acids $(10.71 \%)$ in pangasius than n-3 PUFA content $(2.59 \%)$. These results are confirmed by those for the same species in the current study (Table 2). Gökce et al. (2004) also report a similar regularity for sole; the percentage share of n-3 PUFA (20.2-24.3\%) was lower, whereas n-6 PUFA (6.33-13.93\%) was higher than the values of the present study. The marine fish cod and salmon examined had more n-3 PUFA than n-6 PUFA (Table 2). This is consistent with the results of Grela and Dudek (2007), who report values of n-3 of $36.47 \%$ (cod) and $22.0 \%$ (salmon), and for n-6 PUFA of $5.13 \%$ and $5.03 \%$, respectively. Kołakowska et al. (2000) found the same regularity for flounder, a marine fish. The rainbow trout studied by Diraman and Dibekloglu (2009) had higher values of n-3 PUFA (21.47\%) than n-6 PUFA (10.45\%). The results of the fish from the preset study were similar (Table 2). Ho and Paul (2009) note that farmed Atlantic salmon is a rich source of PUFA, while farmed pangasius has more SFA. The total n-3 PUFA in marine fish species from Turkey was higher than in freshwater fish, whereas the opposite was noted with n-6 PUFA (Özogul et al. 2007).

According to Ugoala et al. (2008) and Kalyoncu (2010), linoleic acid was the most abundant of the n-6 PUFA. Łuczyńska et al. (2008) note that the main fatty acids of n-6 PUFA in other freshwater fish were C18:2 and C20:4. Docosahexaenoic (C22:6 DHA) and eicosapentaenoic (C20:5 EPA) acids were predominant among n-3 PUFA in other fish species studied by various authors (İmre and Sağlik 1998, Njinkoué et al. 2002, Pirestani et al. 2010). Diraman and Dibekloglu (2009) observe that rainbow trout from different locations in Turkey had 7.18 and 6.44\% C18:2 n-6 and 0.60 and 0.48\% C20:4 n-6. The approximate amounts (6.98 and $0.67 \%$, respectively) were noted in African catfish (Özogul et al. 2007). The values for rainbow trout reported by Haliloğlu et al. (2002) were higher. Ho and Paul (2009) note that pangasius contain more C18:2n-6 (8.43\%) and less C20:4n-6 (1.03\%) than salmon (2.16 and 2.49\%, respectively). Grela and Dudek (2007) do not report significant differences in linoleic and arachidonic acid contents between salmon and cod. This is inconsistent with the results of the present study. In contrast to the present findings (Table 2), the percentage of these acids in tilapia from Lake Kyonga was lower than that reported by Kwetegyeka et al. (2008) for catfish. The content of C18:2n-6 in rainbow trout observed by Kołakowska et al. (2000) was higher than the values of this acid in flounder. The same authors observed that, contrarily to DHA, flounder had more EPA than rainbow trout. These data are confirmed by the results of the present study. The values of EPA and DHA in the flounder examined are close to those for the same fish species reported by the authors above, while the rainbow trout studied had less EPA and DHA. Interspecific differences in the content of EPA and DHA in cod and salmon are reported by Grela and Dudek (2007) and confirmed by the results of the present study. Cod contained less DHA and EPA (23.85 and $10.95 \%$, respectively), while salmon had more DHA (13.86\%) and EPA (6.81\%) than the fish species included in the present study. According to Ho and Paul (2009), farmed pangasius has lower DHA and EPA (4.74 and 0.31\%, respectively) than Atlantic salmon (20.20 and 8.27\%, respectively). These results are in good agreement with data from studies of the same fish species. Özogul et al. (2007) and Osibona et al. (2009) report lower values of EPA and DHA in catfish than the fish examined, and similar findings concerning EPA in sole are also reported by Gökce et al. (2004).

Significant differences in the $n-3 / n-6$ ratio between pangasius (0.72) and salmon (5.94) were observed by Ho and Paul (2009). Grela and Dudek 
(2007) note the same differences in cod (7.11) and salmon (4.39). The $\mathrm{n}-3 / \mathrm{n}-6$ ratio in tilapia was higher than in catfish from Lake Kyoga (Kwetegyeka et al., 2008), whereas rainbow trout measured by Kołakowska et al. (2000) had a lower n-3/n-6 ratio than flounder. These findings, with the exception of observations made by Kwetegyeka et al. (2008), are in agreement with those of the present study.

This study demonstrates that freshwater fish, with the exception of pangasius and tilapia, are good sources of n-3 fatty acids, especially EPA and DHA. These fatty acids in freshwater fish were on approximately the same or higher levels in relation to some of the marine fish examined. Pangasius and tilapia were characterized by the highest content of saturated fatty acids, whereas salmon, flounder, and rainbow trout had the highest values of monounsaturated fatty acids.

Author contributions. J.E. designed and performed the research and wrote the manuscript, B.P. performed the research and reviewed the manuscript, M.J.E. wrote and reviewed the manuscript.

\section{References}

Berg H., Nilsson S. 1997 - Determination of fat content in meat and meat products with NMR and SFE - Proc. Euro-Food Chem IX, Interlaken Switzerland, September 24-26: 1: 59-64.

Bienkiewicz G., Domiszewski Z. 2008 - The content of long chain omega 3 unsaturated fatty acids (LC n-3-PUFA) in selected fish species - Mag. Przem. Rybn. 2: 45-46 (in Polish).

Bienkiewicz G., Domiszewski Z., Kuszyński T. 2008 - Freshwater fish as a source of essential unsaturated fatty acids NNKT - Mag. Przem. Rybn. 3: 58-59 (in Polish).

Christie W.W. 1973 - The isolation of lipids from tissues. Recommended Procedures. Chloroform-methanol (2:1, v/v) extraction and "Folch" wash - In: Lipid Analysis. Isolation, separation, identification and structural analysis of lipids (Ed.) W.W. Christie, Pergamon Press Oxford, New York - Toronto - Sydney - Braunschweig: 39-40.

Defilippis A.P., Blaha M.J., Jacobson T.A. 2010 - Omega-3 fatty acids for cardiovascular disease prevention - Curr. Treat. Options Cardiovasc. Med. 12: 365-380.

Diraman H., Dibeklioglu H. 2009 - Chemometric characterization and classification of selected freshwater and marine fishes from Turkey based on their fatty acid profiles - J. Am. Oil Chem. Soc. 86: 235-246.

Drobná Z., Zelenka E., Mrkvicová E., Kladroba D. 2006 Influence of dietary linseed and sunflower oil on sensory characteristics of rainbow trout (Oncorhynchus mykiss) Czech J. Anim. Sci. 51: 475-482.

Glogowski J., Ciereszko A. 2001 - Why we should increase fish consumption, especially that of rainbow trout - Mag. Przem. Rybn. 2: 95-102 (In Polish, with English abstract).

Gökçe M.A., Taşbozan O., Çelik M., Tabakoğlu Ț.S. 2004 Seasonal variations in proximate and fatty acid compositions of female common sole (Solea solea) - Food Chem. 88: 419-423.

Grela E.R., Dudek R. 2007 - Nutrients contents and fatty acid profile in muscle tissue of some marine and freshwater fish - Żyw. Człow. Metab. 34(1/2): 561-565 (in Polish; with English abstract).

Haliloğlu H.I., Aras N.M., Yetim H. 2002 - Comparison of muscle fatty acids of three trout species (Salvelinus alpinus, Salmo trutta fario, Oncorhynchus mykiss) raised under the same conditions - Turk. J. Vet. Anim. Sci. 26: 1097-1102.

Ho B.T., Paul D.R. 2009 - Fatty acid profile of Tra Catfish (Pangasius hypophthalmus) compared to Atlantic Salmon (Salmo Solar) and Asian Seabass (Lates calcarifer) - Inter. Food Res. J. 16: 501-506.

Holub D.J., Holub B.J. 2004 - Omega-3 fatty acids from fish oils and cardiovascular disease - Molec. Cell. Biochem. 263: 217-225.

İmre S., Sağlik S. 1998 - Fatty acid composition and cholesterol content of some Turkish fish species - Turk. J. Chem. 22: 321-324.

Kalyoncu L., Yaman Y., Aktumsek A. 2010 - Determination of the seasonal changes on total fatty acid composition of rainbow trout, Oncorhynchus mykiss in Ivriz Dam Lake, Turkey - Afr. J. Biotech. 9: 4783-4787.

Kołakowska A., Szczygielski M., Bienkiewicz G., Zienkowicz L. 2000 - Some of fish species as a source of $n-3$ polyunsaturated fatty acids - Acta Ichthyol. Piscat. 30: 59-70.

Kris-Etherton P.M., Harris W.S., Appel L.J. 2002 - AHA Scientific Statement: Fish consumption, fish oil, omega-3 fatty acids, and cardiovascular disease - Circulation 106: 2747-2757.

Kwetegyeka J., Mpango G., Grahl-Nielsen O. 2008 - Variation in fatty acid composition in muscle and heart tissues among species and populations of tropical fish in Lakes Victoria and Kyoga - Lipids 43: 1017-1029.

Lecerf J.M. 2007 - Produits de la pęche et acides gras oméga 3. Intéręt en prevention cardio-vasculaire - Phytothérapie 5: 14-21.

Łuczyńska J., Borejszo Z., Łuczyński M.J. 2008 - The composition of fatty acids in muscles of six freshwater fish 
species from the Mazurian Great Lakes (northeastern Poland) - Arch. Pol. Fish. 2: 167-178.

Njinkoué J.M., Barnathan G., Miralles J., Gaydou E.M., Samb A. 2002 - Lipids and fatty acids in muscle, liver and skin of three edible fish from the Senegalese coast: Sardinella maderensis, Sardinella aurita and Cephalopholis taeniops - Comp. Biochem. Physiol. Part B 131: 395-402.

Osibona A.O., Kusemiju K., Akanie G.R. 2009 - Fatty acid composition and amino acid profile of two freshwater species, African catfish (Clarias gariepinus) and tilapia (Tilapia zilli) - Afr. J. Food Agric. Nutr Develop. 9: 608-621.

Osibona A.O. 2011 - Comparative study of proximate composition, amino and fatty acids of some economically important fish species in Lagos, Nigeria - Afr. J. Food Sci. 5: 581-588.

Özogul Y., Özogul F., Alagoz S. 2007 - Fatty acid profiles and fat contents of commercially important seawater and freshwater fish species of Turkey: A comparative study Food Chem. 103: 217-223.

Pirestani S., Sahari M.A., Barzegar M., Nikoopour H. 2010 Lipid, cholesterol and fatty acid profile of some commercially important fish species from South Caspian Sea - J. Food Biochem. 34: 886-895.

Polak-Juszczak L. 2007 - Chemical characteristics of fishes new to the Polish market - Acta Sci. Pol. Piscaria 6: 23-32.

Suloma A., Ogata H.Y., Garibay E.S., Chavez D.R., El-Haroun E.R. 2008 - Fatty acid composition of Nile tilapia Oreochromis niloticus muscles: a comparative study with commercially important tropical freshwater fish in Philippines - In: 8th International Symposium on Tilapia in Aquaculture, Cairo, Egypt 12-14.10.2008, The Central Laboratory for Aquaculture Research, 921-932.

Ugoala Ch., Ndukwe G.I., Audu T.O. 2008 - Comparison of fatty acids of some freshwater and marine fishes - Int. J. Food Saf. 10: 9-17.

Visentainer J.V., D’Addio Noffs M., de Oliveira Carvalbo P., de Almeida V.V., de Oliveira C.C., de Souza N.E. 2007 Lipid content and fatty acid composition of 15 marine fish species from the Southeast Coast of Brazil - J. Am. Oil Chem. Soc. 84: 543-547.

Żegarska Z., Jaworski J., Borejszo Z. 1991 - Evaluation of the Peisker modified method for extracting metyl esters from fatty acids - Acta Acad. Agricult. Tech. Olst. 24: 25-33 (in Polish). 